\title{
Over crimmigratie en discretionair beslissen binnen het Mobiel Toezicht Veiligheid ... of Vreemdelingen ... of Veiligheid?*
}

\author{
Maartje van der Woude, Tim Dekkers \& Jelmer Brouwer
}

\begin{abstract}
Crimmigratie wordt in deze bijdrage begrepen als de toenemende vervlechting van het vreemdelingentoezicht en de strafrechtelijke handhaving. In het onderzoek dat hier wordt beschreven, staat de vraag centraal in hoeverre er reeds in de wetgevings- en beleidscontext keuzes zijn gemaakt die het proces van crimmigratie mogelijk in de hand werken. Door deze keuzes inzichtelijk te maken en te duiden hoe deze zich verhouden tot de street-level beslissingen kan er hopelijk een meer genuanceerde uitspraak worden gedaan over de drijvende krachten achter het proces van crimmigratie. Hiertoe richt het onderhavige onderzoek zich op de Koninklijke Marechaussee en het door hen uitgevoerde Mobiel Toezicht Veiligheid (MTV). Deze vorm van toezicht ziet op de mobiele controles die de KMar in de grensgebieden tussen Nederland, België en Duitsland kan uitvoeren in de treinen en op de wegen, maar ook op de nationale luchthavens op de intra-Schengenvluchten. De KMar en het MTV vormen hiermee een belangrijke schakel in het vreemdelingentoezicht en daarmee mogelijk ook in het proces van crimmigratie. Oorspronkelijk was het de bedoeling dat het MTV illegale migratie zou tegengaan en ontmoedigen, maar het is de vraag in hoeverre dit nog steeds het geval is.
\end{abstract}

\section{Discretionair beslissen binnen de (rechts)handhaving}

Als gevolg van incidenten, klachten, buitenlandse voorbeelden, de ophef rondom 'zwarte piet' en in het bijzonder door de rapporten van Amnesty International Nederland (2013) en het Engelse Open Society Justice Initiative (2013) is in Nederland sinds eind 2013 het debat over discriminatie en selectiviteit in alle hevigheid losgebarsten. Ook recente gebeurtenissen in de Verenigde Staten, in het bijzonder in Ferguson en New York, waarbij zwarte Amerikanen door politiegeweld zijn omgekomen, hebben de Nederlandse discussies over het fenomeen wat bekend is komen te staan als etnisch profileren beïnvloed. Binnen deze discussies is de gedachte dat de politie zich in haar handelen zou laten leiden door (ongefundeerde) aannames dat vooral bepaalde groepen migranten veel criminaliteit veroorzaken en om die reden dus extra aandacht behoeven. Zij zouden als gevolg hiervan bevooroordeeld optreden en daarmee, zoals het model van procedurele rechtvaardigheid helder maakt, groepen burgers van zich vervreemden, met desastreuze gevolgen voor de gepercipieerde legitimiteit van de (rechts)hand-

* De auteurs bedanken graag het Leids Universiteits Fonds en de Gratama Stichting voor hun financiële bijdrage aan het aan dit artikel ten grondslag liggende onderzoek. 
having (Weitzer \& Tuch 2002, 2005; Tyler 2001, 2005, 2011). Hoewel er op basis van voornoemde perceptieonderzoeken zoals die door Amnesty in het Open Society Justice Initiative in Nederland zijn uitgevoerd wel degelijk een zorgwekkend beeld ontstaat over de wijze waarop burgers het handelen van de politie interpreteren, is actueel onderzoek wat zich echt richt op het bestuderen en analyseren van het beslisproces van politieambtenaren nog relatief schaars (Aalberts 1990; Bovenkerk 2014; Cankaya 2012; Svensson, Sollie \& Saharso 2012; Van der Leun e.a. 2014).

Waar het handelen van de reguliere politie als gevolg van voornoemde gebeurtenissen nu in het bijzonder in de schijnwerpers is komen te staan, draait de discussie in de kern om de bredere vraag hoe actoren binnen de (rechts)handhaving omgaan met de aan hen door de wetgever toebedeelde discretionaire beslisruimte en in hoeverre daarbinnen ruimte is voor en sprake is van oneigenlijk gebruik. Dit is een vraag die het werkveld van de politie overstijgt en bijvoorbeeld ook speelt bij de wijze waarop de in deze bijdrage centraal staande Koninklijke Marechaussee (hierna: KMar) invulling geeft aan haar taak als 'grens (vreemdelingen) politie' bij de toepassing van de bevoegdheid Mobiel Toezicht Veiligheid (hierna: MTV). Dit zijn de mobiele identiteitscontroles die de KMar in de grensgebieden tussen Nederland, België en Duitsland kan uitvoeren in de treinen, op de wegen en op de nationale luchthavens op de zogeheten intra-Schengenvluchten. In het kader van het in november 2015 af te ronden onderzoeksproject 'Beslissen in Grensgebieden' is door de auteurs uitvoerig juridisch/beleidsmatig en empirisch onderzoek verricht naar de discretionaire beslisruimte die marechaussees hebben bij het MTV en de wijze waarop zij daar vervolgens concreet invulling aan geven. ${ }^{1}$ Doel van dit onderzoek is niet alleen om zicht te krijgen op de uitkomsten van de discretionaire beslissingen van individuele marechaussees, maar ook op verschillende factoren en processen die deze individuele beslissingen mogelijk (onbewust) kunnen beïnvloeden. Met betrekking tot dit laatste, de bredere context die van invloed is op het handelen van individuele beslissingen van actoren binnen de handhaving spreekt Hawkins (2003) over het in kaart brengen van het 'decisionfield' waarbinnen marechaussees hun beslissing vormgeven. Waar de contouren, de grenzen, van het decision-field volgens Hawkins worden bepaald door de wet, wordt het kader nader ingevuld door beleidskeuzes. Bushway en Frost (2014) refereren aan de constante interactie tussen wat zij 'Type A' en 'Type B' discretionairy decision-making noemen, waarbij Type A ziet op de individuele beslissingen die worden genomen door individuele actoren binnen de (straf)rechtspleging en Type B op de beslissingen die op het niveau van beleid en wetgeving worden genomen over de discretionaire ruimte waarbinnen Type A-beslissingen genomen moeten worden. Individuele discretionaire beslissingen worden natuurlijk niet

1 Het onderzoeksproject 'Beslissen in Grensgebieden' is van start gegaan in oktober 2013 en zal naar verwachting worden afgerond in november 2015. In het kader van de binnen dit onderzoek centraal staande onderzoeksvragen is er gedurende een periode van dertien maanden onder meer ruim 800 manuren geobserveerd tijdens MTV-diensten, tevens zijn er veertien focusgroepgesprekken met marechaussees betrokken bij de operationele uitvoering van het MTV gevoerd. Voor meer informatie over het onderzoeksproject kan contact worden opgenomen met Maartje van der Woude via m.a.h.vanderwoude@law.leidenuniv.nl. 
alleen bepaald door het decision-field, ook spelen allerhande interpretatieve processen en associaties die mede ingekleurd zijn door kennis, ervaring, opvoeding, enzovoort, een belangrijke rol. Dit laatste wordt ook wel aangeduid als het proces van framing. Het is in dit stadium van het beslisproces waar individuele persoonlijke vooroordelen en stereotyperingen de besluitvorming letterlijk kunnen 'kleuren', waardoor het gevaar van etnisch profileren op de loer ligt (Tillyer \& Hartley 2010; Van der Woude \& Van der Leun 2013). Onderzoek heeft echter uitgewezen dat de wijze waarop ambtenaren binnen de rechtshandhaving invulling geven aan hun discretionaire beslisruimte sterker dan aanvankelijk werd gedacht, wordt beïnvloed door de aard en vorm van de juridische kaders en beleidscontext waarbinnen de beslissingen genomen moeten worden (Hawkins 1989). De juridische en beleidskaders vormen het eerste kompas waarop men vaart en een eerste belangrijke afbakening van de eigen individuele beslisruimte. Indien deze kaders onduidelijk of tegenstrijdig zijn, of vatbaar voor uiteenlopende interpretatie, dan kan dit van grote invloed zijn op de wijze waarop individuele ambtenaren vervolgens invulling geven aan hun discretionaire bevoegdheden.

Om beslissingen van individuele politieambtenaren of marechaussees te begrijpen en te duiden is het dus van groot belang om ook de juridische en beleidsmatige context waarbinnen de beslissing is genomen aan een grondige analyse te onderwerpen. Pas dan is het mogelijk om op basis van de uitkomsten van deze beslissingen uitspraken te doen over mogelijk oneigenlijk handelen - of dit nu gaat om etnisch profileren of andersoortig oneigenlijk handelen. In deze bijdrage zal een dergelijke analyse van het MTV en het handelen van de KMar hierbinnen worden geboden om op die manier te achterhalen in hoeverre er daarbinnen door de wetgever en beleidsmakers reeds keuzes zijn gemaakt en beslissingen zijn genomen die bijdragen aan de toenemende vervlechting van het vreemdelingentoezicht en de strafrechtelijke handhaving, ook wel bekend als het proces van crimmigratie (Miller 2005; Stumpf 2006, 2011; Chacon 2012; Aliverti 2012; Staring 2012; Garcia Hernandez 2014; Van der Leun 2010; Van der Leun \& Van Schijndel 2012; Van der Woude, Van der Leun \& Nijland 2014). Criminaliteit, veiligheid en (internationale) migratie worden hierbij in toenemende mate als nauw aan elkaar verwante begrippen gezien (Mitsilegas 2015), wat volgens Bosworth en Guild (2008) niet alleen heeft geleid tot een meer punitieve houding ten aanzien van migratiecriminaliteit, maar ook tot het gericht inzetten van verschillende vormen van beleid om (ongewenste) buitenstaanders uit te sluiten. Alle zeilen - zowel de strafrechtelijke als de bestuursrechtelijke - worden bijgezet om illegaal verblijf en migratiecriminaliteit tegen te gaan.

Ondanks de toename van onderzoek naar dit fenomeen, verschillen auteurs sterk van mening over de drijvende factoren achter het proces van crimmigratie en de mate waarin verschillende actoren binnen de veiligheids- en immigratieketen hierbij mogelijk een rol spelen. Vanwege de grote discretionaire ruimte die ambtenaren die zijn betrokken bij de operationele uitvoering van het veiligheids- en immigratiebeleid genieten - waaronder in Nederland onder meer de KMar - lijkt desalniettemin in het bijzonder het handelen van deze street-level ambtenaren (Lipsky 1980) kritisch onder de loep te worden genomen. Zo beweert Motomura (2011: 1819): '(...) the discretion to stop persons is the strongest driver behind 
the process of crimmigration, since it enables racial profiling and makes streetlevel officers responsible for funneling immigrants into systems dealing with immigration crime or criminal violations.' Hoewel de beslissingen van street-level ambtenaren ontegenzeggelijk een belangrijke factor zijn in het proces van crimmigratie, lijkt het, in het licht van de door Hawkins $(1996,2003)$ maar ook door Bushway en Frost (2013) benadrukte connectie tussen beslissingen die op het niveau van beleid en wetgeving worden genomen en het handelen op street-level, wat te eenvoudig om street-level ambtenaren als de belangrijkste - the strongest drijfveer aan te wijzen.

De KMar en het MTV vormen een belangrijke schakel in het vreemdelingentoezicht en de grensbewaking en daarmee mogelijk ook in het proces van crimmigratie. Zoals in het vervolg van deze bijdrage nog uitgebreid aan de orde zal komen, is de oorspronkelijke doelstelling van het in 1994 in het leven geroepen MTV het in grensgebieden tegengaan en ontmoedigen van illegale migratie. Waar dit op het eerste gezicht een ogenschijnlijk duidelijk afgebakende - vreemdelingenrechtelijke - taak lijkt, is er onder invloed van de toenemende publieke en politieke zorgen over migratie en de link tussen migratie en criminaliteit de afgelopen decennia regelmatig gesleuteld aan de wettelijke kaders van het MTV, waardoor het de vraag is in hoeverre de taakstelling nog steeds zo duidelijk is afgebakend. Door voor wat betreft het MTV en handelen van de KMar hierbinnen de keuzes en beslissingen op het niveau van wetgeving en beleid inzichtelijk te maken en te analyseren, beoogt deze bijdrage nader licht te werpen op het proces van crimmigratie. De vraag die in deze bijdrage dan ook centraal zal staan is:

Hoe hebben de juridische en beleidsmatige kaders van het MTV zich sinds de inwerkingtreding ontwikkeld en hoe verhouden de beslissingen die hierbij op wetgevingsen beleidsniveau zijn genomen zich tot het proces van crimmigratie?

Deze vraag zal worden beantwoord op basis van een analyse van beleidsstukken, (inter)nationale wet- en regelgeving en jurisprudentie. In het hiernavolgende zal eerst een nadere beschouwing plaatsvinden van de mogelijke relatie tussen discretionaire beslisruimte en het proces van crimmigratie (par. 2). $\mathrm{Na}$ een uiteenzetting van de gehanteerde onderzoeksmethoden in paragraaf 3 worden vervolgens in paragraaf 4 en 5 de resultaten van de beleidsanalyse (par. 4) respectievelijk de wettelijke kaders van de juridische basis van het MTV, juridische analyse van wetgeving en jurisprudentie gepresenteerd (par. 5). In de slotparagraaf zullen we terugkomen op de hiervoor opgeworpen onderzoeksvraag.

\section{Crimmigratie en discretionaire beslisruimte}

Alvorens de aandacht te vestigen op de KMar en het Mobiel Toezicht Veiligheid, is het van belang om kort nader stil te staan bij de wijze waarop in de (inter)nationale literatuur de concepten crimmigratie en discretionaire beslisruimte met elkaar in verband zijn gebracht. Zoals in de vorige paragraaf onder verwijzing naar Motomura (2011) reeds aangegeven, wordt in de Amerikaanse literatuur de 
discretionaire beslisruimte van politieambtenaren met het oog op crimmigratie dikwijls geproblematiseerd, vanwege de mogelijkheid dat er keuzes zouden worden gemaakt op basis van etnische of raciale vooroordelen (Miller 2005; Stumpf 2006; Pratt 2008, 2010; Koulish 2010). Waar deze studies een belangrijk - en zorgwekkend - licht schijnen op de toenemende criminalisering van 'anderen' en op allerhande vooroordelen over groepen minderheden, is het belangrijk om in te zien dat het proces van crimmigratie hierdoor slechts deels verklaard kan worden. Deze ruimte voor ongelijke toepassingen van het recht is immers inherent aan het bestaan van discretionaire bevoegdheden en daarmee niet uniek voor het proces van crimmigratie (Crank, Flaherty \& Giacomazzi 2007; Van Halderen \& Lasthuizen 2013). Het proces van crimmigratie omvat meer dan discrimineren of oneigenlijk selecteren, het ziet op een andere wijze van denken over de wijze waarop criminaliteit en immigratie als maatschappelijke problemen aangepakt moeten worden. Het overstijgt daarmee de individuele keuzes die in het veld gemaakt worden en moet meer gezien worden als een fundamentele wijziging waarop er op maatschappelijk niveau wordt gedacht over criminelen en immigranten. Beide groepen worden gezien als gevaarlijke of onwenselijke anderen, waartegen - met welk middel dan ook - opgetreden moet worden (Garland 2001; Bosworth \& Guild 2008; Simon 2006). Volgens Sklansky (2012) kan het proces van crimmigratie niet los worden gezien van de over de bredere linie van het recht zichtbare tendens van ad hoc instrumentalisering. Hieronder verstaat hij:

'(...) a manner of thinking about law and legal institutions that downplays concerns about consistency and places little stock in formal legal categories, but instead sees legal rules and legal procedures simply as a set of interchangeable tools. In any given situation, faced with any given problem, officials are encouraged to use whichever tools are most effective against the person or persons causing the problem' (Sklansky 2012, 161).

De ogenschijnlijke ratio achter het proces van crimmigratie past duidelijk binnen deze trend: het net van sociale controle wordt op deze manier dusdanig uitgebreid, dat mogelijke risicovolle individuen (lees: vreemdelingen of criminelen) hoe dan ook aangepakt kunnen worden. Of dit nu (deels) via het strafrecht of (deels) via het migratierecht gebeurt, doet daarbij niet ter zake. Laat staan de vraag welke gevolgen een dergelijk hybride systeem van straf- en migratierechtelijke maatregelen heeft voor de rechtspositie van de betrokken rechtssubjecten. Immers, waar de handhaving via het strafrecht met de nodige rechtswaarborgen is omkleed, is dit niet of nauwelijks het geval indien het via het bestuursrecht geschiedt (Miller 2005; Stumpf 2006; Chacon 2012; Van der Woude, Van der Leun \& Nijland 2014). Als er maar op een zo efficiënt mogelijke wijze gehandhaafd kan worden. Sklansky merkt op dat om dit te bereiken er een ontwikkeling zichtbaar is waarbij ambtenaren in het veld worden uitgerust met zowel strafrechtelijke als immigratierechtelijke discretionaire bevoegdheden waarvan individuele ambtenaren ad hoc besluiten welke bevoegdheden ingezet worden: als er maar 'succes' wordt geboekt. Hoewel ook Sklansky hiermee een belangrijke rol toebedeelt aan de discretionaire beslissingen genomen op street-level, geeft hij - anders dan andere 
auteurs - aan dat dit slechts een uitvloeisel is van de over de brede linie zichtbare bedrijfsmatige benadering van het recht als instrument ter vergroting van de maatschappelijke veiligheid. Volgens Sklansky's visie zou het proces van crimmigratie dus veel meer moeten worden gezien als een uitvloeisel van op beleidsniveau genomen keuzes en daarbinnen bestaande opvattingen over hoe er op een zo efficiënt mogelijke wijze opgetreden kan worden tegen onveiligheid veroorzaakt door criminelen of migranten. Het proces van crimmigratie sluit daarmee naadloos aan bij de over de gehele linie van de criminaliteitsbestrijding steeds groter wordende rol van het bestuursrecht naast het strafrecht.

\section{Een analyse van discours wetgeving en jurisprudentie}

Om zicht te krijgen op het decision-field, de juridische en beleidsmatige context als een van de factoren waardoor de beslissingen van individuele marechaussees beïnvloed worden, is er in de eerste plaats gebruikgemaakt van een beleidsanalyse (Koemans 2011). De beleidsanalyse probeert inzicht te geven in de gedachtegangen en denkbeelden omtrent de doelstelling en toepassing van het MTV op het niveau van de politiek en het beleid. ${ }^{2}$ De primaire bron voor deze analyse is het parlementaire debat zoals deze te zien is in de beleidsdocumenten. Deze documenten worden verzameld in verschillende digitale databases. Drie databases zijn gebruikt bij het zoeken van de benodigde documenten: OpMaat, Tweedekamer.nl en Staten Generaal Digitaal. Deze drie databases bevatten alle verschillende officiele documenten, zoals handelingen van Kamerdebatten, beleidsrapportages, beleidsevaluaties en wetgeving.

Het MTV is ongeveer twintig jaar geleden tot stand gekomen. Het zoeken naar documenten binnen een tijdsbestek van twintig jaar zou een erg grote hoeveelheid documenten opleveren. Om dit aantal beter behapbaar te maken voor een discoursanalyse, zijn er drie perioden geselecteerd binnen deze twintig jaar. De eerste periode is die van 1992 tot en met 1994. Hoewel het MTV officieel pas startte in mei van 1994, wordt een in februari 1992 ingediende motie gezien als de start van de ontwikkeling van het MTV (De Weger 2006). Door deze periode mee te nemen in de analyse, kunnen de ontwikkeling, prioriteiten en doelstelling van het MTV in de beginfase in kaart worden gebracht. De tweede geselecteerde periode loopt van 2001 tot en met 2003. De aanslagen van 11 september 2001 worden wereldwijd gezien als een belangrijk keerpunt op het gebied van grenstoezicht (Ackleson 2005; Donaldson 2005; Miller 2005; Aradau \& Van Munster 2007). De laatste periode loopt van 2011 tot en met 2013. In juni 2011 worden door de toenmalige minister van Immigratie en Asiel beperkingen op het MTV gelegd, nadat de Raad van State had bepaald dat het MTV te veel gelijkenis vertoonde met grenscontrole. Om te zien hoe deze beperkingen het politieke en beleidsdiscours beïnvloeden, wordt deze periode ook meegenomen in de analyse.

2 De beleidsanalyse vormt eveneens een belangrijke component binnen het eerder genoemde overkoepelende onderzoek 'Beslissen in Grensgebieden'. Het in kaart brengen van ontwikkelingen in de doelstelling en visie op de tenuitvoerlegging van het MTV was hierbij slechts één van de aspecten waarop is gelet. 
Uit de gevonden resultaten van elke periode is een selectie gemaakt. Het selectieproces bestaat uit drie stappen. De eerste selectie is gedaan op basis van de titel van het document. Omdat de titel niet altijd zichtbaar was in de zoekmachines van de gebruikte databases, is er bij de tweede stap van selectie gekeken naar de inhoudsopgave en onderwerpen van de documenten. Wanneer de inhoud ervan hierna nog steeds niet duidelijk was, is er door middel van een snelle scan van het document bepaald of het relevante informatie bevatte of niet. De geselecteerde documenten zijn geanalyseerd in het programma Atlas-Ti. In totaal zijn er 451 documenten geselecteerd voor de analyse. Of de documenten informatie bevatten over de doelstelling en tenuitvoerlegging van het MTV, was een van de expliciete punten waar tijdens deze selectie op is gelet. Van deze documenten bevatten 202 documenten informatie die daadwerkelijk is gebruikt in de analyse.

Aansluitend op de beleidsanalyse is er gekeken naar de wijze waarop de in de beleidscontext gemaakte keuzes werden vertaald naar concrete wet- en regelgeving, door middel van een analyse van die wet- en regelgeving, maar ook - waar relevant - door een analyse van jurisprudentie.

\section{Van Mobiel Toezicht Vreemdelingen naar Mobiel Toezicht Veiligheid op beleidsniveau}

De beleidsanalyse laat zien dat er in de periode 1992 tot heden veel is veranderd voor wat betreft de (beoogde) doelstelling en tenuitvoerlegging van het MTV. In deze paragraaf zullen we het beeld schetsen zoals dat uit de analyse naar voren is gekomen.

In de jaren negentig wordt ondanks het niet of nauwelijks aanwezig zijn van exacte cijfers en getallen in Nederland in toenemende mate politieke aandacht besteed aan de instroom van illegale vreemdelingen. Desondanks vormen vooronderstellingen en abstracties van incidenten en enkele concrete gegevens, bronnen voor schattingen, beeldvorming en (nadere) beleidsvorming (Witte \& Wijkhuis 2001). In 1994 leidden verschillende discussies omtrent de mogelijke en noodzakelijke maatregelen om de toestroom van illegale immigranten te beperken tot de oprichting van het MTV. Tegen de achtergrond van de inwerkingtreding van het Schengenakkoord in 1995 en bijgevolg het wegvallen van grenscontroles aan de binnengrenzen van de lidstaten, nam de druk op het vreemdelingenbeleid in de eerste helft van de jaren negentig sterk toe. ${ }^{3}$ Het openstellen van de grenzen naar aanleiding van de Schengen uitvoeringsovereenkomst (SUO) baarde het parlement zorgen. Niet alleen vanwege de mogelijk aanzuigende werking die het wegvallen van de grenzen zou hebben op migranten die zich illegaal in Nederland zouden willen vestigen, maar ook vanwege een mogelijke toename van grensover-

3 Kamerstukken I 1992/93, 22140, nr. 52; Kamerstukken I 1992/93, 22140, nr. 52c; Kamerstukken II 1992/93, TK 27; Kamerstukken II 1992/93, TK 28; Kamerstukken II 1992/93, TK 78; Kamerstukken II 1992/93, 21501-23, nr. 8; Kamerstukken II 1992/93, 22735, nr. 5. 
schrijdende (drugs)criminaliteit. ${ }^{4}$ In het politieke debat over grenstoezicht ging er als gevolg hiervan ook veel aandacht uit naar de vraag of criminaliteitsbestrijding onderdeel moest worden van de taak van de KMar. De KMar was op dat moment vooral gespecialiseerd in immigratiezaken, maar had daarnaast een ondersteunende rol voor de politie, zoals vastgelegd in de Politiewet van 1994. De angst voor meer grensoverschrijdende criminaliteit was voor sommige politici reden om een beroep te doen op deze ondersteunende rol om criminaliteit te bestrijden en criminelen buiten te houden (zie hierover ook: De Weger 2006). Ondanks de plannen die gemaakt werden om de KMar ook een rol te laten spelen in de bestrijding en opsporing van de grensoverschrijdende criminaliteit, kreeg de KMar met de inwerkingtreding van het MTV op 24 maart 1994 - waarbij de afkorting toen nog stond voor het Mobiel Toezicht Vreemdelingen - echter aanvankelijk louter de taak om, conform de oorspronkelijke doelstelling van het MTV, in een zo vroeg mogelijk stadium illegaal verblijf van vreemdelingen tegen te gaan, en toekomstige illegale immigratie te ontmoedigen. ${ }^{5}$ In totaal werden - gefaseerd - 448 ambtenaren van de KMar beschikbaar gesteld 'voor het bedienen van controlepunten en het patrouilleren in de vorm van vliegende brigades aan en achter de grens'. ${ }^{6}$ Witte en Wijkhuis (2001) hebben in het kader van een WODC-onderzoek naar de effectiviteit van het MTV in de periode 1994-2001 met diverse sleutelfiguren gesproken die betrokken waren bij de oprichting van het MTV in deze periode. Een van hun respondenten doet daarbij een opmerkelijke uitspraak met het oog op het daadwerkelijke doel van het MTV: 'Het mobiel toezicht vreemdelingen is in eerste instantie een "politiek instrument". Van belang is te laten zien dat er een effectief vreemdelingentoezicht plaatsvindt. Doel is een geloofwaardig aantal illegale vreemdelingen aan te houden en terug te sturen.' Het MTV was dus duidelijk niet bedoeld als instrument ter opsporing en bestrijding van criminaliteit, maar juist als een instrument in het kader van het operationele vreemdelingentoezicht gericht op het zenden van een signaal naar zowel de samenleving als potentiële illegale grensgangers, dat illegale migratie als probleem serieus wordt genomen en wordt aangepakt.

In de jaren na invoering van het MTV verschuift het discours - of beter het breidt uit - van zorgen over het optreden tegen illegale migratie naar zorgen over het gebruik van vervalste identiteitspapieren door illegale migranten, alsook over de mogelijke betrokkenheid van criminele organisaties hierbij. ${ }^{7}$ Door het aan het licht komen van deze strafbare gedragingen - identiteitsfraude en mensensmokkel - middels het MTV, laaide de discussie over de rol van het MTV als zijnde een eveneens belangrijk instrument voor strafrechtelijke handhaving weer op. Hierbij werd in het bijzonder gewezen op de mogelijke rol die het MTV in de bestrijding van mensensmokkel en van fraude met reis- en identiteitsdocumenten zou kun-

4 Kamerstukken II 1992/93, TK 28; Kamerstukken II 1992/93, TK 86; Kamerstukken II 1992/93, 22562, nr. 10; Kamerstukken II 1993/94, TK 66.

5 Kamerstukken II 2002/03, 26269, nr. 6 (Brief van de minister-president aan de voorzitter van de Tweede Kamer der Staten-Generaal d.d. 22 maart 1994).

$6 \quad$ Notitie Inzet Koninklijke Marechaussee Asielzoekers, Den Haag 22 maart 1994.

7 Kamerstukken II 2002/03, 27204, nr. 19; Kamerstukken II 2002/03, 26269, nr. 51; Kamerstukken II 2001/02, just020517; Kamerstukken II 2002/03, 27204, nr. 18. 
nen spelen. ${ }^{8}$ Om recht te doen aan deze belangrijke status, maar ook om duidelijkheid te scheppen in de bevoegdheden van marechaussees ten aanzien van het afhandelen van dit soort strafrechtelijke gedragingen waarop zij tijdens de uitoefening van het MTV konden stuiten, ${ }^{9}$ kreeg de KMar in 2006 de zelfstandige taak om mensensmokkel en fraude met reis- en identiteitsdocumenten te bestrijden (art. 4 lid 1 sub g Politiewet 2012). Voor het MTV betekende deze wijziging concreet dat indien marechaussees in het vervolg bij de tenuitvoerlegging van het MTV stuitten op mensensmokkel of identiteitsfraude, er geen overdracht meer aan de politie hoefde plaats te vinden en de zaak zelfstandig afgehandeld kon en mocht worden. Het moeten overdragen van strafrechtelijke 'vondsten' aan de politie zoals voorheen noodzakelijk was, bleek in de praktijk hoogst inefficiënt en daardoor onwenselijk. ${ }^{10}$ Met betrekking tot de bestrijding van overige (georganiseerde) grensoverschrijdende misdaad - zoals witwassen of drugscriminaliteit werd duidelijk bepaald dat dit weliswaar viel binnen de taakstelling van de KMar, maar dat deze taken slechts konden worden uitgevoerd in de vorm van formele, vooraf schriftelijk vastgelegde en niet structurele, assistentieverlening aan de politie. ${ }^{11}$

In de periode 2006-2010 staat de rechtmatigheid van de MTV-controles stevig ter discussie. De reden daarvoor was gelegen in het feit dat de MTV-controles te zeer een verkapte vorm van permanente grenscontrole zouden zijn, hetgeen in strijd werd geacht met de Schengengrenscode en het daarin verankerde vrij verkeer van personen, goederen, diensten en kapitaal (De Roos 2011; Van der Woude \& Van Berlo 2015). Als gevolg van deze onduidelijkheid over de verhouding van het MTV tot de Schengengrenscode wordt het MTV tijdelijk gestaakt totdat er in 2010 door het Europees Hof van Justitie duidelijkheid werd geschapen voor wat betreft de rechtmatigheidskwestie. Het MTV mocht weer uitgevoerd worden, zij het in aangepaste vorm, waarbij de intensiteit en frequentie van het aantal controles aan

8 Kamerstukken II 2002/03, 27204, nr. 19; Kamerstukken II 2002/03, 26269, nr. 51; Kamerstukken II 2001/02, 27204, nr. 17.

9 Kamerstukken II 2005/06, 30557, nr. 3.

10 Kamerstukken II 2005/06, 30557, nr. 3, p. 4.

11 Kamerstukken II 1992/93, 22562, nr. 23. 
banden zijn gelegd. ${ }^{12}$ Opvallend is dat er binnen het beleidsdiscours vanaf dit moment een naamswijziging heeft plaatsgevonden. Niet langer wordt er gesproken over het Mobiel Toezicht Vreemdelingen: in plaats daarvan wordt gesproken over het Mobiel Toezicht Veiligheid. Deze naamsverandering lijkt een breder handelingskader voor de KMar te impliceren, waarbij er mogelijk niet alleen op vreemdelingenrechtelijke kwesties, maar ook op veiligheidsgerelateerde zaken gecontroleerd mag worden. Dit bredere kader wordt weerspiegeld door de aangepaste doelstelling van het MTV, zoals die vanaf dat moment werd gebruikt in verschillende officiële (beleids)documenten: 'Het doel van deze controles is het tegengaan van illegaal verblijf en het bestrijden van vormen van grensoverschrijdende criminaliteit.' ${ }^{13}$ De reden van de naamsverandering en het doel werden beschreven in een brief van de minister van Immigratie, Integratie en Asiel. ${ }^{14}$ Volgens de minister werd er gedurende de MTV-controles immers ook regelmatig gestuit op criminele zaken niet zijnde mensensmokkel of identiteitsfraude, waardoor de controles niet alleen effect zouden kunnen hebben op illegale migratie en daaraan gerelateerde criminaliteit, maar ook op de nationale veiligheid en andere vormen van grensoverschrijdende criminaliteit. Zonder dat de vreemdelingenrechtelijke grondslag verlaten zou moeten worden, doet de naamsverandering volgens de minister beter recht aan het belang van het instrument voor de Nederlandse samenleving.

\section{Duidelijkheid op wetgevingsniveau?}

Op beleidsniveau lijkt er aldus enigszins geworsteld te zijn met de naamstelling en de doelstelling van het MTV. Is het MTV een instrument van strafrechtelijke opsporing, van vreemdelingenrechtelijk toezicht of allebei? Omdat dit voor de invulling van de beslissingen die door marechaussees in het kader van het MTV worden genomen wel degelijk uitmaakt, is het belangrijk om ook te bezien op

12 Eind 2010 oordeelde de Afdeling bestuursrechtspraak van de Raad van State dat uit het arrest van het Hof van Justitie van de EU in de zaak Melki en Abdeli/Frankrijk volgt dat het enkele feit dat het doel van een MTV-controle verschilt van dat van een grenscontrole, niet betekent dat een MTV-controle reeds daarom niet hetzelfde effect kan hebben als een grenscontrole. Om die reden heeft het in overwegingen 74 en 75 aangegeven dat een nationale wettelijke regeling op grond waarvan een controlebevoegdheid wordt uitgeoefend, dient te voorzien in het noodzakelijke kader voor het uitoefenen van die bevoegdheid om te waarborgen dat de uitoefening ervan niet hetzelfde effect als een grenscontrole kan hebben. Zie: ABRvS 28 december 2010, ECLI:NL:RVS:2010:BP0427, HvJ EU 22 juni 2010, nr. C-188/10 (Melki ) en nr. C 189/10 (Abdeli). Om te waarborgen dat het MTV feitelijk niet systematisch wordt uitgevoerd en daarmee niet hetzelfde effect heeft als grenscontrole in de zin van de Schengengrenscode zoals die wordt uitgeoefend aan de buitengrenzen van het Schengengebied, heeft de regering in art. 4.17a Vreemdelingenbesluit 2000 (Vb 2000) de intensiteit en frequentie van het MTV genormeerd. Zie: besluit van 30 mei 2011, houdende wijziging van het Vreemdelingenbesluit 2000 in verband met nadere regels over het toezicht ter bestrijding van illegaal verblijf na grensoverschrijding (Stb. 2011, 262).

13 Kamerstukken II 2011/12, 19637, 1393; Kamerstukken II 2011/12, 19637, 1485; Kamerstukken II 2010/11, 32317, 68 .

14 Kamerstukken II 2011/12, 19637, 1526. 
welke wijze deze beleidsmatige worsteling zich heeft vertaald naar de concrete wettelijke kaders waaraan marechaussees bij het nemen van hun beslissingen gebonden zijn.

\section{Duidelijkheid over de selectiebeslissing?}

De KMar is qua taakstelling een interessante actor, vanwege het sterk hybride karakter. Zo zijn marechaussees zowel belast met de uitvoering van militaire politietaken als met een aantal belangrijke civiele politietaken. Deze civiele politietaken van de KMar zijn limitatief vastgelegd in artikel 4 lid 1 Politiewet 2012. De MTV-taak is vastgelegd in sub f: 'de uitoefening van de bij of krachtens de Vreemdelingenwet 2000 (hierna: Vw) opgedragen taken (...)'. Binnen de vreemdelingenwet is de regelgeving rondom het MTV voorts verankerd in artikel $50 \mathrm{Vw}$ jo. 4.17a en 4.17b Vreemdelingenbesluit (hierna: $\mathrm{Vb}$ ). Artikel $50 \mathrm{Vw}$ vormt de wettelijke grondslag voor het door marechaussees in het kader van het MTV mogen staande houden van personen ter vaststelling van hun identiteit, nationaliteit en verblijfsrechtelijke positie. De grondslag is - in lijn met de oorspronkelijke doelstelling van het MTV - gelegen in "het bestrijden van illegaal verblijf na grensoverschrijding'. Uit de Vreemdelingencirculaire volgt dat voor het staande houden van personen in het kader van een MTV geen redelijk vermoeden van illegaal verblijf is vereist, zoals dat bij een staandehouding in het kader van het binnenlands vreemdelingentoezicht wel het geval is. Op basis van onder meer eigen ervaringsgegevens van de KMar kunnen voertuigen of personen worden geselecteerd voor een controle. ${ }^{15}$ Hieruit volgt dat in beginsel iedereen die de grens passeert, kan worden staande gehouden ter controle op illegaal verblijf. Weliswaar is in de tekst van artikel 50 de bevoegdheid tot MTV-controle ontegenzeglijk gerelateerd aan het begrip 'grensoverschrijding', maar dat begrip noopt niet tot het oordeel dat de uitoefening van de bevoegdheid louter is beperkt tot personen die daadwerkelijk en onmiddellijk voorafgaand aan de uitoefening van de bevoegdheid de grens hebben overschreden. Tegen de achtergrond van het doel van de bevoegdheid kan artikel 50 lid 1 Vw 2000 aldus worden uitgelegd, dat de bevoegdheid mag worden aangewend ter bestrijding van illegaal verblijf in de grensstreken. De beperking tot de grensstreken is noodzakelijk ter afbakening van de bevoegdheid tot controle in het kader van het binnenlands vreemdelingentoezicht zoals uitgevoerd door de vreemdelingenpolitie.

\section{Duidelijkheid over de vreemdelingenrechtelijke of strafrechtelijke taakstelling?}

Hoewel marechaussees volgens de wet gelijk zijn gesteld aan opsporingsambtenaren (art. 126 jo. 141 Wetboek van Strafvordering, hierna: Sv), lijkt het erop dat de wetgever heeft willen voorkomen dat marechaussees en politieambtenaren in de praktijk ook daadwerkelijk gelijkelijk opereren. Volgens artikel 4 lid 4 Politiewet 2012 moet 'een krachtens artikel 141 Sv aangewezen militair van de Koninklijke Marechaussee, hoewel bevoegd tot de opsporing van alle strafbare feiten, zich onthouden van optreden anders dan in het kader van de uitoefening van zijn politietaken'. Zoals in de vorige paragraaf besproken, vormen de bestrijding van men- 
sensmokkel en van fraude met reis- en identiteitsdocumenten de uitzondering op deze regel (art. 4 lid 1 sub g Politiewet 2012).

Opmerkelijk is dat waar dit een duidelijke vingerwijzing lijkt te zijn van de wetgever voor wat betreft de beperkingen aan de bevoegdheden van de KMar, er vervolgens aan het overschrijden van de in lid 4 verankerde instructienorm niet het gevolg van onrechtmatigheid van dit handelen is verbonden, maar slechts de mogelijkheid tot het opleggen van niet nader gespecificeerde 'disciplinaire repercussies'. ${ }^{16}$ Aangezien jurisprudentie op dit punt afwezig is, is het onduidelijk in hoeverre dergelijke repercussies in de praktijk ook daadwerkelijk worden opgelegd (Sackers 2013). Inmiddels weten we ook dat gemaakte fouten in het vreemdelingenrechtelijke voortraject - zoals een vreemdelingenrechtelijk onrechtmatige staandehouding in het kader van het MTV - geen gevolgen hoeven te hebben in de daaruit voortvloeiende strafzaak. Hoewel de feitencomplexen in de twee zaken waarin de Hoge Raad zich boog over deze vraag niet specifiek zagen op het oneigenlijk gebruik van het MTV als instrument voor de opsporing van grensoverschrijdende criminaliteit niet zijnde mensensmokkel of identiteitsfraude, lijkt uit beide zaken te kunnen worden afgeleid dat zo lang een onrechtmatige staandehouding niet plaatsvond in het kader van het voorbereidend onderzoek naar het tenlastegelegde strafrechtelijke feit, er - juridisch gezien - niets aan de hand is (De Jonge van Ellemeet 2014). ${ }^{17}$ Met andere woorden, indien er in het kader van een MTV-controle een voertuig wordt gestopt omdat de marechaussee van mening is dat de inzittenden mogelijk in het bezit zijn van verdovende middelen of grote hoeveelheden contant geld - gedragingen die niet stroken met de vreemdelingenrechtelijke grondslag van het MTV - dit weliswaar onrechtmatig, maar voor de verdere afhandeling van de uit de stop voortvloeiende strafzaken verder niet relevant of problematisch is. De staandehouding heeft formeel immers plaatsgevonden in het kader van het vreemdelingentoezicht en niet in het kader van het voorbereidend onderzoek naar de feiten.

Het MTV biedt aldus veel ruimte voor het zelfstandig oordeel van individuele marechaussees om in de grensgebieden personen en voertuigen te selecteren. Doordat er geen redelijk vermoeden van illegaal verblijf aangetoond behoeft te worden en er ook niet per se sprake hoeft te zijn van aantoonbare grensoverschrijding, geven de wettelijke kaders van de Vreemdelingenwet, het Vreemdelingenbesluit en de Vreemdelingencirculaire weinig tot geen handvatten aan de concrete invulling van de selectiebeslissingen van marechaussees. Daar komt nog eens bij dat het wettelijk kader voor wat betreft de concrete taakstelling - vreemdelingenrechtelijk of toch ook helemaal strafrechtelijk - ook enigszins ambigu is, daar er aan het overschrijden van de formele taakstelling geen duidelijke consequenties verbonden lijken te worden. 


\section{Terug naar crimmigratie ...}

In deze bijdrage hebben we een beeld geschetst van de wettelijke context en de beleidskaders, het eerder genoemde decision-field (Hawkins 2003), waarbinnen marechaussees bij de tenuitvoerlegging van het MTV opereren, om op die manier zicht te krijgen in hoeverre deze context en kaders zich verhouden tot het proces van crimmigratie, de vervlechting van het strafrecht en het vreemdelingenrecht. Voordat we komen tot een slotoverweging waarin we de centrale vraag zullen beantwoorden, is het van belang om te benadrukken dat deze bijdrage ziet op de papieren werkelijkheid. Hiermee is dus niets gezegd over de mate waarin die overeenkomt met de praktijk van het MTV. Zoals in de openingsparagraaf reeds is aangegeven met betrekking tot het beter in kaart brengen van het verschijnsel etnisch profileren, is het ook voor het daadwerkelijk kunnen duiden en oordelen over de beslissingen die worden genomen in de context van het MTV noodzakelijk om empirisch - kwalitatief - onderzoek uit te voeren naar de keuzes die door politieambtenaren en marechaussees in de uitoefening van hun taakstelling gemaakt worden en de redeneringen en aannames die hieraan ten grondslag liggen.

Uit het voorgaande komt het complexe (juridische) karakter van het MTV naar voren: het betreft een instrument in het kader van het vreemdelingentoezicht, uitgevoerd door militaire politiefunctionarissen die naast hun vreemdelingenrechtelijke controlebevoegdheid algemeen opsporingsambtenaar zijn. In de tenuitvoerlegging van het MTV genieten deze functionarissen, de marechaussees, voorts een aanzienlijke discretionaire ruimte ten aanzien van het selecteren van personen en/of voertuigen voor een nadere controle. Hoewel de wettelijke grondslag van het MTV met zich meebrengt dat deze selectie in de eerste plaats moet zijn ingekleurd door de vreemdelingenrechtelijke grondslag van het MTV - het tegengaan en voorkomen van illegaal verblijf in Nederland - is het de vraag in hoeverre hierbij niet ook, bewust dan wel onbewust, meer strafrechtelijke associaties een rol spelen.

Wat betekenen de in deze bijdrage weergegeven ontwikkelingen in de wettelijke en beleidskaders van het MTV nu voor het proces van crimmigratie? In welke mate zijn er op dat niveau beslissingen genomen die dit proces in de hand zouden kunnen werken? Wanneer we kijken naar het MTV, dan moet geconcludeerd worden dat er zowel op beleidsniveau als op wetgevingsniveau keuzes zijn gemaakt die op street-level tot onduidelijkheid kunnen leiden ten aanzien van de exacte taakstelling en de daarbij behorende bevoegdheden. De vervlechting van strafrechtelijke handhaving en vreemdelingenrechtelijk toezicht lijkt daarmee een fundamenteel kenmerk van het MTV en niet louter toe te schrijven aan het handelen van individuele marechaussees. De gewijzigde naamstelling van het MTV onderstreept dit nog eens extra. Veiligheid - en daarmee ook de handhaving daarvan is onmiskenbaar een onderdeel geworden van het MTV. Deze observatie neemt echter niet weg dat het proces van crimmigratie ook mede wordt gedreven door opvattingen en beslissingen genomen op het street-level. Tegen de achtergrond van een steeds meer op efficiëntie en output ingerichte strafrechts- en vreemde- 
lingenketen in combinatie met een maatschappelijk en politiek discours waarin reeds geruime tijd vreemdelingen en criminaliteit als (deels) aan elkaar verwante kwesties worden beschouwd, is het wellicht niet vreemd dat deze associaties ook leven in de praktijk van het toezicht en de handhaving (Van der Woude \& Van der Leun 2013). Dit vormt vanzelfsprekend geen rechtvaardigingsgrond, maar geeft wel aan dat de verantwoordelijkheid voor dit soort praktijken breder moet worden gezocht dan alleen bij de mannen en vrouwen die in de grensgebieden hun taak uitoefenen. Zeker wanneer blijkt dat er over die taak geen eenduidig beeld bestaat.

Zoals gezegd, zoekt het gros van de onderzoekers de drijfveer van het proces van crimmigratie in het discretionaire handelen van verschillende actoren binnen de opsporing en de handhaving - in het bijzonder de politie en het Openbaar Ministerie (Motomura 2011;Wadhia 2015; Hernandez 2013; Eagly 2011; Reyes 2012; Stumpf 2015). Op basis van deze bijdrage kan echter worden vastgesteld dat de voorwaarden voor het proces van crimmigratie reeds gecreëerd worden op wetgevings- en beleidsniveau. Deze observatie wordt onderschreven door Galligan (1986) die stelt dat '(...) the very heart of the discretionary process lies within legislative and policy decisions'. Voor een adequaat en goed begrip van het proces van crimmigratie is het daarmee van groot belang een integraal perspectief te hanteren, waarbij de discretionaire beslissingen van verschillende actoren ook in relatie en interactie tot elkaar worden beschouwd. De keuzes en beslissingen die op het niveau van het beleid en de wetgever genomen worden, dienen daarbij als een belangrijk beginpunt. Een ogenschijnlijk op zichzelf staande discretionaire beslissing maakt in werkelijkheid mogelijk onderdeel uit van een breder, meer complex geheel aan discretionaire beslissingen van meerdere betrokken actoren. Het is belangrijk om het bestaan van interactie tussen verschillende actoren te erkennen: wat de output is voor de ene actor, dient als input voor de ander, met alle gevolgen van dien voor het begrijpen en verklaren van een proces als crimmigratie (Hawkins 1992).

\section{Literatuur}

Aalberts, M.M.J. (1990) Politie tussen discretie en discriminatie: Operationeel vreemdelingentoezicht in Nederland. Arnhem: Gouda Quint.

Ackleson, J. (2005) Border security in risk society. Journal of Borderlands Studies, 20(1), $1-22$.

Aliverti, A. (2014) Making people criminal: The role of the criminal law in immigration enforcement. Theoretical Criminology.

Amnesty International (2013) Proactief politieoptreden vormt risico voor mensenrechten in Nederland. Etnisch profileren onderkennen en aanpakken. Amsterdam: Amnesty International Nederland.

Aradau, C. \& R. van Munster (2007) Governing terrorism through risk: Taking precautions, (un)knowing the future. European journal of international relations,13(1), 89-115.

Beken, T. van der (2011) Grensvervaging tussen interne en externe veiligheid. Tijdschrift voor Veiligheid, 10(4), 59-69. 
Bosworth, M. \& M. Guild (2008) Governing Through Migration Control. British Journal of Criminology, 48, 703-719.

Bovenkerk, F. (2014) 'Twee Marokkanen op een scooter? Die houd ik aan'. Ethnic profiling in Nederland. Te verschijnen in: M. Davidovic \& A.B. Terlouw (red.), Diversiteit en discriminatie: Onderzoek naar processen van in- en uitsluiting (p. 203-222), Amsterdam: Amsterdam University Press.

Bushway, S.D. \& B. Forst (2013) Studying Discretion in the Processes that Generate Criminal Justice Sanctions. Justice Quarterly, 30(2), 199-222.

Çankaya, S. (2012) De controle van marsmannetjes en ander schorriemorrie: Het beslissingsproces tijdens proactief politiewerk. Den Haag: Boom Lemma uitgevers.

Chacon, J.M. (2012) Overcriminalizing Immigration. Journal of Criminal Law \& Criminology, 102(3), 613-652.

Crank, J.P., D. Flaherty \& A. Giacomazzi (2007) The Noble Cause: An Empirical Assessment. Journal of Criminal Justice, 35(1), 103-116.

De Jonge van Ellemeet, H. (2014) Vreemdelingen(zaken) in de strafkamer van de Hoge Raad. Nederlands Juristenblad, 2, 88-94.

Donaldson, J.W. (2005) Fencing the line: analysis of the recent rise in security measures along disputed and undisputed boundaries. In: Global Surveillance and Policing: Borders, Security, Identity (p. 173-193), Portland: Willan Publishing.

Eagly, I. (2011) Local Immigration Prosecution: A Study of Arizona Before SB 1070. 58 UCLA Law Review, 1749-1817.

Galligan, D.J. (1986) Discretionary Powers: A Legal Study of Official Discretion. Clarendon Press.

Garcia Hernandez, C. (2014) Creating Crimmigration. BYU Law Review, 6(4), 1457-1516.

Garland, D. (2001). Culture of Control. Crime and Social Order in Contemporary Society. Chicago: University of Chicago Press.

Halderen, R.C. van \& K. Lasthuizen (2013) Creatief gebruik van bevoegdheden. Een explorerend onderzoek binnen de Nederlandse politie. Tijdschrift voor Veiligheid, 1(12), 16-36.

Hawkins, K. (1989) 'FATCATS' and Prosecution in a Regulatory Agency: A Footnote on the Social Construction of Risk. Law \& Policy, 11(3), 370-391.

Hawkins, K. (1992) The uses of discretion. Oxford: Clarendon Press.

Hawkins, K. (2003) Order, rationality and silence: some reflections on criminal justice decision-making. In: L. Gelsthorpe \& N. Padfield (eds.), Exercising Discretion. Decisionmaking in the criminal justice system and beyond. London: Routledge.

Hernandez, C.C.G. (2013) Creating Crimmigration. Brigham Young University Law Review, 6, 1457-1516.

Koemans, M. (2011) The war on antisocial behaviour: Rationales underlying antisocial behaviour policies. Comparing British and Dutch discourse analyses. Leiden.

Koulish, R. (2010) Immigration and American Democracy. Subverting the Rule of Law. New York: Routledge.

Leun, J.P. van der (2010) Crimmigratie. Antwerpen-Apeldoorn: Maklu.

Leun, J.P. van der \& A. van Schijndel (2012) Uitbuiting uit zicht? Getuigenverklaringen van gesmokkelde migranten nader bekeken aan de hand van indicatoren voor mensenhandel. Tijdschrift voor Veiligheid, 11(3), 20-37.

Leun J.P. van der, M.A.H. van der Woude \& S. de Ridder (2013) Crimmigratie in de Lage Landen: Smeltende Grenzen?. Strafblad, 221-228.

Leun, J.P. van der, M.A.H. van der Woude, R.D. Vijverberg, R.P.M. Vrijhoef \& A.J. Leupen (2014) Etnisch Profileren in Den Haag? Een verkennend onderzoek naar beslissingen en opvattingen op straat. Den Haag: Boom Lemma uitgevers. 
Lipsky, M. (1980) Street Level Bureaucracy. Dilemmas of the Individual in Public Services. New York: Russel Sage Foundation.

Miller, T.A. (2005) Blurring the Boundaries between Immigration and Crime Control after September 11th. Boston College Third World Law Journal, 25(1), 80-123.

Mitsilegas, V. (2015) The Criminalisation of Migration in Europe. Challenges for Human Rights and the Rule of Law. London: Springer.

Motomura, H. (2011) The discretion that matters: Federal immigration enforcement, state and local arrests and the civil - criminal line. UCLA Law Review, 58, 1819-1858.

Open Society Justice Initiative \& Amnesty International (2013) Gelijkheid onder druk: De impact van etnisch profileren. Amsterdam: Amnesty International Nederland.

Pratt, A. (2008) Securing Borders: Detention and Deportation in Canada. Vancouver: UBC Press.

Reyes, M.I. (2012) Constitutionalizing Immigration Law: The vital role of judicial discretion in the removal of lawful permanent residents. Temple Law Review, 84, 637-700.

Sackers, H.J.B. (2013) Politiewet 2012. In: C.P.M. Cleiren \& M.J.M. Verpalen (red.), Strafvordering. De tekst van het Wetboek van Strafuordering en enkele aanverwante wetten voorzien van commentaar (Tekst \& commentaar) (p. 2669-2755). Deventer: Kluwer.

Sklansky, D.A. (2013) Crime, Immigation and Ad Hoc Instrumentalism. New Criminal Law Review, 15(2), 157-223.

Staring, R. (2012) Crimmigratie en de morele economie van illegale vreemdelingen. PROCES, Tijdschrift voor Strafrechtspleging.

Stumpf, J.P. (2006) The crimmigration crisis: Immigrants, crime, and sovereign power. American University Law Review, 56.

Stumpf, J.P. (2011) Doing Time: Crimmigration Law and the Perils of Haste. UCLA Law Review, 58, 1705-1748.

Stumpf, J.P. (2015) D(e)volving Discretion: Lessons from the Life and Times of Secure Communities. American University Law Review, 64, 1259-1284.

Svensson, J.S., H. Sollie \& S. Saharso (2012) Proactief handhaven en gelijk behandelen. Amsterdam: Reed Business.

Tillyer, R. \& R.D. Hartley (2010) Driving racial profiling research forward: Learning lessons from sentencing research. Journal of Criminal Justice, 38(4), 657-665.

Tyler, T.R. (2001) Public trust and confidence in legal authorities: What do majority and minority group members want from the law and legal institutions?. Behavioral Sciences and the Law, 19(2), 215-235.

Tyler, T.R. (2005) Policing in Black and White: Ethnic group differences in trust and confidence in the police. Police Quarterly, 8(3), 322-342.

Tyler, T.R. (2011) Trust and legitimacy: Policing in the USA and Europe. European Journal of Criminology, 8(4), 254-266.

Wadhia, S.S. (2015) Beyond Deportation: The Role of Prosecutorial Discretion in Immigration Cases. New York: New York University Press.

Weger, M. de (2006) De Binnenlandse veiligheidstaken van de Nederlandse krijgsmacht. Assen: Koninklijke Van Gorcum.

Weitzer, R. \& S.A. Tuch (2002) Perceptions of racial profiling: Race, class, and personal experience. Criminology, 40(2), 435-456.

Weitzer, R. \& S.A. Tuch (2005) Determinants of public satisfaction with the police. Police Quarterly, 8(3), 279-297.

Witte, R. \& R. Wijkhuis (2001) Effectief Mobiel Toezicht Vreemdelingen (WODC Rapportage).

Woude, M.A.H. van der \& J.P. van der Leun (2013) De Nederlandse veiligheidscultuur als katalysator voor etnisch profileren?. Tijdschrift over Cultuur \& Criminaliteit, 3(2), 123-136. 
Woude, M.A.H. van der, J.P. van der Leun \& J.A. Nijland (2014) Crimmigration in the Netherlands. Law \& Social Inquiry, 39(3), 560-579.

Woude, M.A.H. \& P. van Berlo (2015) Crimmigration at the Internal Borders of Europe? Examining the Schengen Governance Package. Utrecht Law Review, 11(1), 61-79. 